\title{
Cyanidin-3-glucoside isolated from mulberry fruit protects pancreatic $\beta$-cells against oxidative stress-induced apoptosis
}

\author{
JONG SEOK LEE ${ }^{1,2^{*}}$, YOUNG RAE KIM ${ }^{2 *}$, IN GYU SONG ${ }^{2}$, SUK-JIN HA ${ }^{2}$, \\ YOUNG EON KIM ${ }^{3}$, NAM-IN BAEK ${ }^{4}$ and EOCK KEE HONG ${ }^{2}$
}

\author{
${ }^{1}$ National Institute of Biological Resources, Incheon 404-708; ${ }^{2}$ Department of Bioengineering and Technology, \\ Kangwon National University, Chuncheon, Gangwon-do 200-701; ${ }^{3}$ Division of Metabolism and Functionality Research, \\ Korea Food Research Institute, Seongnam, Gyeonggi-do 463-746; ${ }^{4}$ Department of Oriental Medicinal \\ Materials and Processing, Kyung Hee University, Yongin, Gyeonggi-do 446-701, Republic of Korea
}

Received July 15, 2014; Accepted November 21, 2014

DOI: 10.3892/ijmm.2014.2013

\begin{abstract}
The extract obtained from berries contains high amounts of anthocyanins, and this extract is used as a phytotherapeutic agent for different types of diseases. In this study, we examined the cytoprotective effects of cyanidin-3-glucoside $(\mathrm{C} 3 \mathrm{G})$ isolated from mulberry fruit against pancreatic $\beta$-cell apoptosis caused by hydrogen peroxide $\left(\mathrm{H}_{2} \mathrm{O}_{2}\right)$-induced oxidative stress. The MIN6 pancreatic $\beta$-cells were used to investigate the cytoprotective effects of $\mathrm{C} 3 \mathrm{G}$ on the oxidative stress-induced apoptosis of cells. Cell viability was examined by MTT assay and lipid peroxidation was assayed by thiobarbituric acid (TBA) reaction. Immunofluorescence staining, flow cytometry and western blot analysis were also used to determine apoptosis and the expression of proteins associated with apoptosis. Our results revealed that $\mathrm{H}_{2} \mathrm{O}_{2}$ increased the rate of apoptosis by stimulating various pro-apoptotic processes, such as the generation of intracellular reactive oxygen species (ROS), lipid peroxidation, DNA fragmentation and caspase-3 activation. However, C3G reduced the $\mathrm{H}_{2} \mathrm{O}_{2}$-induced cell death in the MIN6N pancreatic $\beta$-cells. In addition, we confirmed that $\mathrm{H}_{2} \mathrm{O}_{2}$ activated mitogenactivated protein kinases (MAPKs), such as extracellular signal-regulated kinase (ERK), c-Jun $\mathrm{NH}_{2}$-terminal kinase (JNK) and p38 MAPK. C3G inhibited the phosphorylation of ERK and p38 without inducing the phosphorylation of JNK. Furthermore, C3G regulated the intrinsic apoptotic pathwayassociated proteins, such as proteins belonging to the $\mathrm{Bcl}-2$
\end{abstract}

Correspondence to: Professor Eock Kee Hong, Department of Bioengineering and Technology, College of Engineering, Kangwon National University, 192-1 Hyoja-2-dong, Chuncheon, Gangwon-do 200-701, Republic of Korea

E-mail: ekhong@kangwon.ac.kr

*Contributed equally

Key words: diabetes, oxidative stress, mulberry, anthocyanin, apoptosis family, cytochrome $c$ and caspase-3. Taken together, our results suggest that $\mathrm{C} 3 \mathrm{G}$ isolated from mulberry fruit has potential for use as a phytotherapeutic agent for the prevention of diabetes by preventing oxidative stress-induced $\beta$-cell apoptosis.

\section{Introduction}

Diabetes is one of the major metabolic diseases among adults worldwode. Type 1 diabetes, classified as insulin-dependent diabetes mellitus, is caused by the loss of insulin secretion due to the destruction of pancreatic $\beta$-cells (1). This leads to an increase in blood sugar levels and a decrease in the energy transfer to other organs, which results in various secondary complications (2). Therefore, the protection of pancreatic $\beta$-cells is crucial for preventing the onset of type 1 diabetes. Under homeostatic conditions, potentially toxic reactive oxygen species (ROS) are primarily generated by mitochondrial respiratory metabolism, and are subsequently neutralized effectively by cellular antioxidant defense mechanisms. However, the excessive generation of ROS, such as super oxide anions $\left(\mathrm{O}_{2}^{-}\right)$ and hydrogen peroxide $\left(\mathrm{H}_{2} \mathrm{O}_{2}\right)$ due to environmental stress results in significant oxidative damage to cell structures, such as DNA, the mitochondria and cell membranes $(3,4)$.

Recent studies have demonstrated that antioxidants present in natural products protect cells by reducing $\mathrm{H}_{2} \mathrm{O}_{2}$-induced oxidative stress in vitro and in vivo (5-7). This indicates the importance of isolating compounds with antioxidant activity and the characterization of their antioxidant mechanisms. Mulberry fruit is a well known medicinal plant and has long been used for the treatment of different types of diseases (8-10). Recent studies have suggested that anthocyanins isolated from mulberry fruit exert anti-aging, anti-hyperlipidemic and anticancer effects (11-13). In particular, a representative of the anthocyanins isolated from mulberry fruit, cyanidin-3-glucoside $(\mathrm{C} 3 \mathrm{G})$, is present in high quantities in mulberry fruit and is considered a phytotherapeutic agent due to its anti-oxidant properties $(11,14)$.

In the present study, we investigated the protective effects of $\mathrm{C} 3 \mathrm{G}$ isolated from mulberry fruit against the $\mathrm{H}_{2} \mathrm{O}_{2}$-induced apoptosis of MIN6N pancreatic $\beta$-cells. 


\section{Materials and methods}

Preparation of sample. The mulberry fruits $(15 \mathrm{~kg})$ were extracted in $70 \%$ ethanol (36 liters) for $24 \mathrm{~h}$ at room temperature 3 times. The solvent was filtered, concentrated using an evaporator, redissolved in distilled water and lyophilized (yield, 14.6\%). The powder obtained from the mulberry extract was soaked in $n$-hexane for $24 \mathrm{~h}$ to remove fats and oils. C3G in the powder was extracted with acidified methanol (methanol/1.0 N HCl, 85:15, v/v), centrifuged at 12,000 x g for $15 \mathrm{~min}$ to remove the precipitate and then filtered through a $0.45-\mu \mathrm{m}$ filter. The purified anthocyanin extract was evaporated at $46^{\circ} \mathrm{C}$ to dryness and stored $4^{\circ} \mathrm{C}$. The sample was identified by diluting the purified anthocyanin powder with the solvent (methanol/ $\mathrm{H}_{2} \mathrm{O} /$ formic acid, 75:20:5) and performing high-performance liquid chromatography (HPLC). The pure C3G standard (kuromanin chloride) and purified anthocyanin isolated from the mulberry fruit were identified using the HPLC retention time (Fig. 1), and their purity was $>99 \%$, as shown by HPLC. Reversed-phase HPLC was performed using a Waters 486 detector (Water, Milford, MA, USA) under the following conditions: column, $\mu$ Bondapak C18 (Waters, $3.9 \times 300 \mathrm{~mm}$ ); flow rate, $0.5 \mathrm{ml} / \mathrm{min}$; injection volume, $10 \mu \mathrm{l}$; column temperature, $46^{\circ} \mathrm{C}$. The absorbance was recorded at $520 \mathrm{~nm}$ using a UV/Vis spectrophotometer (Spectronic Instruments; Thermo Fisher Scientific, Waltham, MA, USA). The identified $\mathrm{C} 3 \mathrm{G}$ powder was redissolved in medium and filtered using a $0.22-\mu \mathrm{m}$ filter before using it in cell culture.

Chemicals. Dulbecco's modified Eagle's medium (DMEM), fetal bovine serum (FBS), penicillin/streptomycin (PS) and trypsin-EDTA were purchased from Gibco (Grand Island, NY, USA). Dichlorodihydrofluorescein-diacetate $\left(\mathrm{H}_{2} \mathrm{DCF}-\mathrm{DA}\right)$ and the apoptosis assay kit were obtained from Molecular Probes (Carlsbad, CA, USA). The pure C3G standard (kuromanin chloride), $\mathrm{H}_{2} \mathrm{O}_{2}$, Hoechst 33342 and the mitochondria isolation kit were purchased from Sigma-Aldrich (St. Louis, MO, USA). The rat/mouse insulin enzyme-linked immunosorbent assay (ELISA) kit was obtained from Linco Research Inc. (St. Charles, MO, USA). Antibodies against c-Jun $\mathrm{NH}_{2}$-terminal kinase (JNK; \#9252), phosphorylated (p-)JNK (\#9255S), extracellular signalregulated kinase (ERK; \#4695), p-ERK (\#9101S), p38 (\#9212), p-p38 (\#4631S) and horseradish peroxidase (HRP)-linked anti-rabbit IgG (\#7074) were purchased from Cell Signaling Technology (Beverly, MA, USA). Antibodies against $\beta$-actin (sc-47778), Bax (sc-493), Bcl-2 (sc-7382), caspase-3 (sc-7272) and HRP-linked goat anti-mouse IgG (sc-2005) were purchased from Santa Cruz Biotechnology, Inc. (Santa Cruz, CA, USA). The mitogen-activated protein kinase (MAPK) inhibitors, PD98059 and SB203580, were obtained from Calbiochem (La Jolla, CA, USA). All other chemicals were of analytical grade.

Cell culture and treatment. The MIN6N pancreatic $\beta$-cells were derived from a mouse pancreatic islet cell line. The cells were provided by Professor H.Y. Kwon (College of Medicine, Hallym University, Chuncheon, Korea). The MIN6N $\beta$-cells were cultured in DMEM (11 mM glucose; Gibco) supplemented with $10 \%$ inactivated $\mathrm{FBS}$ and $1 \%$ penicillin-streptomycin (PS) at $37^{\circ} \mathrm{C}$ in a humidified $5 \% \mathrm{CO}_{2}$ incubator. The cells were cultured to $\sim 90 \%$ confluence and were harvested with $0.25 \%$
trypsin-EDTA. The cells were harvested and subcultured for an additional $48 \mathrm{~h}$ in DMEM. The cells were maintained under these culture conditions for all the experiments. The cells were seeded in 6- or 12-well plates, pre-incubated with the indicated concentrations of $\mathrm{C} 3 \mathrm{G}$ for $20 \mathrm{~h}$ at $37^{\circ} \mathrm{C}$, and were then treated with $\mathrm{H}_{2} \mathrm{O}_{2}$.

Cell viability assay. The MIN6N $\beta$-cells were seeded into 12 -well plates and were incubated for $20 \mathrm{~h}$. The cells were exposed to the drug treatments $\left(\mathrm{C} 3 \mathrm{G}, \mathrm{H}_{2} \mathrm{O}_{2}\right)$ at the indicated concentrations for the indicated periods of time. Cell viability was evaluated using the 3-[4,5-dimethylthiazol-2-yl]-2,5-diphenyltetrazolium bromide (MTT) assay, which is based on the reduction of a tetrazolium salt by mitochondrial dehydrogenase in viable cells. After the treatments, $500 \mu \mathrm{g} / \mathrm{ml}$ MTT solution were added to each well followed by incubation for $3 \mathrm{~h}$ at $37^{\circ} \mathrm{C}$. The formazan crystals in each well were dissolved in isopropyl alcohol and the absorbance of each well was measured at $595 \mathrm{~nm}$ using an ELISA microplate reader (model 550; Bio-Rad, Hercules, CA, USA).

Measurement of lipid peroxidation. Lipid peroxidation was assayed using the thiobarbituric acid (TBA) reaction, as previously described (15). Briefly, the treated cells were washed with cold phosphate-buffered saline (PBS), harvested with $0.25 \%$ trypsin-EDTA and homogenized in cold $1.15 \% \mathrm{KCl}$. Subsequently, a $100 \mu 1$ aliquot of the homogenized cells was mixed with $0.2 \mathrm{ml}$ of $8.1 \%$ sodium dodecyl sulfate (SDS), $1.5 \mathrm{ml}$ of $20 \%$ acetic acid (pH 3.6) and $1.5 \mathrm{ml}$ of $0.8 \%$ TBA. The mixture was then heated to $95^{\circ} \mathrm{C}$ for $2 \mathrm{~h}$. After cooling to room temperature, an n-butanol/pyridine mixture $(15: 1, \mathrm{v} / \mathrm{v})$ was added and the mixture was then shaken for 5 min prior to centrifugation at $1,000 \mathrm{x} \mathrm{g}$ for $10 \mathrm{~min}$. The supernatant was isolated, and the absorbance was measured at $535 \mathrm{~nm}$.

Measurement of intracellular ROS scavenging activity and image analysis. To determine the effects of $\mathrm{C} 3 \mathrm{G}$ on oxidative stress-induced ROS generation, we added $5 \mu \mathrm{M}$ of $\mathrm{H}_{2}$ DCF-DA in PBS (pH 7.38) to the treated cells, and measured the fluorescence at excitation and emission wavelengths of 485 and $535 \mathrm{~nm}$, respectively, using a microplate spectrofluorometer (Molecular Devices Corp., Sunnyvale, CA, USA). Image analysis to determine the production of intracellular ROS was performed by seeding the MIN6N $\beta$-cells in coverslip-loaded 12-well plates. The cells were treated with the indicated concentrations of $\mathrm{C} 3 \mathrm{G}$ for $20 \mathrm{~h}$ followed by the addition of $0.7 \mathrm{mM} \mathrm{H}_{2} \mathrm{O}_{2}$. Following incubation for $4 \mathrm{~h}, \mathrm{H}_{2}$ DCF-DA solution was added to each well of the plate, and the cells were incubated further for $2 \mathrm{~h}$ at $37^{\circ} \mathrm{C}$. Images of the stained cells were acquired using a fluorescence microscope (Nikon, Melville, NY, USA).

Determination of apoptotic cells. The ditermination of apoptotic cells was carried out as perviously described (16). Cells undergoing apoptosis were examined using a fluorescein isothiocyanate (FITC)-labeled Annexin V/propidium iodide (PI) apoptosis detection kit (Molecular Probes, Eugene, OR, USA) according to the manufacturer's instructions. In brief, the cells were harvested, washed with PBS and centrifuged to collect the cell pellet. The number of cells was adjusted to $1 \times 10^{6}$ cells $/ \mathrm{ml}$. Subsequently, the cells were resuspended in 

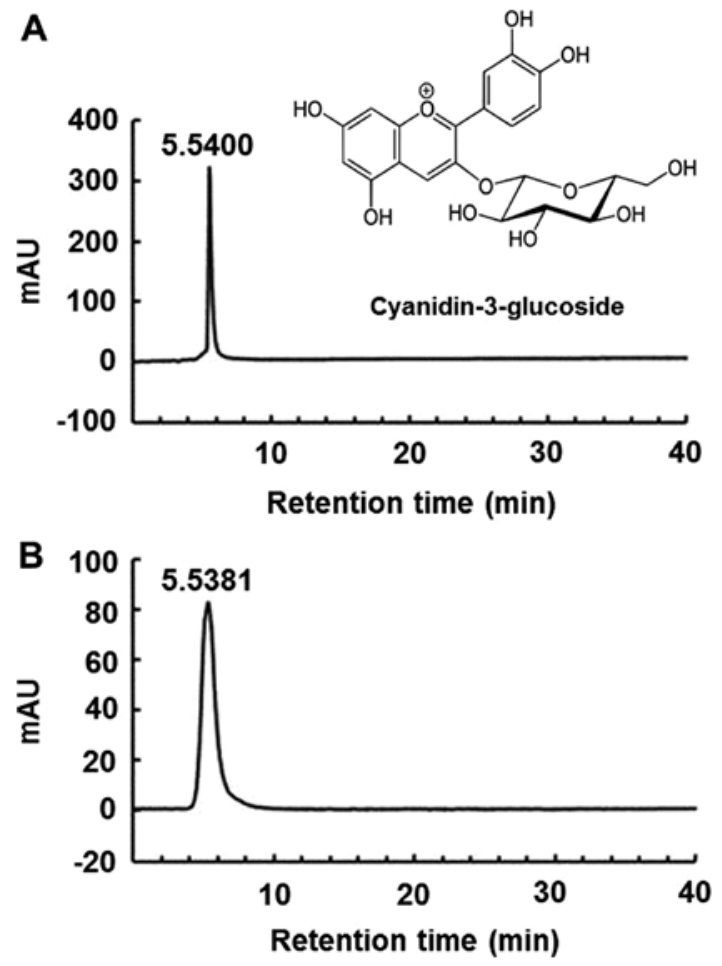

Figure 1. High-performance liquid chromatography (HPLC) chromatogram of cyanidin-3-glucoside (C3G) isolated from mulberry fruit. (A) HPLC chromatogram of the pure $\mathrm{C} 3 \mathrm{G}$ standard $(1 \mathrm{mg} / \mathrm{ml})$. (B) $\mathrm{C} 3 \mathrm{G}$ isolated from mulberry fruit $(250 \mu \mathrm{g} / \mathrm{ml})$. Detection was performed at $520 \mathrm{~nm}$.

binding buffer [10 $\mathrm{mMHEPES}, 140 \mathrm{mM} \mathrm{NaCl}$ and $2.5 \mathrm{mM} \mathrm{CaCl}_{2}$ (pH 7.4)] and stained with FITC-labeled Annexin V/PI at room temperature for 15 min under light-protected conditions. Flow cytometric analysis was performed using a FACSCalibur flow cytometer (Becton-Dickinson, Mountain View, CA, USA). The percentages of apoptotic cells were calculated using CellQuest software (Becton-Dickinson). Cells in the early phase of apoptosis were Annexin V-positive and PI-negative; however, cells in the late phase of apoptosis were positive for both Annexin $\mathrm{V}$ and PI. The apoptotic index (\%) was calculated as the sum of cells in the early and late phases of apoptosis divided by the total number of events.

To determine the effects of $\mathrm{C} 3 \mathrm{G}$ on $\mathrm{H}_{2} \mathrm{O}_{2}$-induced DNA fragmentation, the MIN6N $\beta$-cells were labeled using the cell-permeable DNA-specific fluorescent dye, Hoechst 33342. The cells that showed homogeneously stained nuclei were considered viable, whereas the presence of chromatin fragmentation indicated apoptosis. The MIN6N $\beta$-cells treated with various concentrations of $\mathrm{C} 3 \mathrm{G}$ were seeded in 12-well plates; Hoechst 33342 (stock $10 \mathrm{mg} / \mathrm{ml}$ ) was added to each well followed by $15 \mathrm{~min}$ of incubation at room temperature. Images of the stained cells were acquired using a fluorescence microscope (Nikon) to examine the degree of DNA condensation and/or fragmentation.

Western blot analysis. The treated cells were washed in 1X PBS and lysed in lysis buffer for $30 \mathrm{~min}$ on ice. The lysates were centrifuged at $12,000 \mathrm{x} \mathrm{g}$ for $30 \mathrm{~min}$ at $4^{\circ} \mathrm{C}$. The supernatant was collected, and the protein content in the supernatant was measured using a Bio-Rad protein assay kit prior to analysis.
The total or fractionated protein samples were loaded and separated using SDS-polyacrylamide gel electrophoresis (PAGE) and transferred onto nitrocellulose membranes. The membranes were blocked with $5 \%$ non-fat powdered milk in $1 \mathrm{X}$ Tris-buffered saline containing $0.1 \%$ Tween-20 (TBS-T) for $1 \mathrm{~h}$, and were then incubated with primary antibodies at $4^{\circ} \mathrm{C}$ overnight. Finally, the membranes were treated with HRP-linked secondary antibodies for $1 \mathrm{~h}$ at room temperature. The membranes were washed with TBS-T after each antibody binding reaction. The detection of each protein was performed using an enhanced chemiluminescence kit (Millipore Co., Billerica, MA, USA).

Measurement of caspase- 3 activity. The treated MIN6N $\beta$-cells were lysed in $500 \mu \mathrm{l}$ lysis buffer consisting of $10 \mathrm{mM}$ Tris- $\mathrm{HCl}(\mathrm{pH} 7.5), 10 \mathrm{mM} \mathrm{NaH}{ }_{2} \mathrm{PO}_{4} / \mathrm{NaHPO}_{4}$ (PH 7.5), $130 \mathrm{mM} \mathrm{NaCl}, 1 \%$ Triton X-100 and $10 \mathrm{mM}$ NaPPi. Caspase-3 activity in the lysates was evaluated using a caspase assay kit (BD Biosciences, San Diego, CA, USA) according to the manufacturer's instructions.

Measurement of insulin secretion. The cell culture medium was collected from the treated cells, and the level of insulin released in the medium was measured using a rat/mouse insulin ELISA kit according to the manufacturer's instructions.

Statistical analysis. All measurements were from at least 3 independent experiments, and the values are expressed as the means \pm standard error (SE). Statistical analysis was performed using a Student's t-test. A value of $\mathrm{P}<0.05$ was considered to indicate a statistically significant difference.

\section{Results}

Optimal concentration of $\mathrm{C} 3 \mathrm{G}$ and $\mathrm{H}_{2} \mathrm{O}_{2}$ in MIN6N $\beta$-cells. To determine the concentrations of $\mathrm{C} 3 \mathrm{G}$ that could be used without affecting the viability of the MIN6N $\beta$-cells, we performed an MTT assay. The cells were seeded in 12-well plates and incubated for $24 \mathrm{~h}$; subsequently, various concentrations of $\mathrm{C} 3 \mathrm{G}$ were added to the cells followed by incubation for $20 \mathrm{~h}$. C3G was well tolerated (cell viability, 86.6\%) up to a concentration of $200 \mu \mathrm{g} / \mathrm{ml}$; subsequently, cell viability decreased in a dose-dependent manner. At 300 and $500 \mu \mathrm{g} / \mathrm{ml}$, C3G decreased cell viability by 83.9 and $80.3 \%$, respectively. Thus, we concluded that the optimal concentration of $\mathrm{C} 3 \mathrm{G}$ for use in further experiments was up to $200 \mu \mathrm{g} / \mathrm{ml}$ (Fig. 2).

In this study, $\mathrm{H}_{2} \mathrm{O}_{2}$ was used to induce oxidative stress in the MIN6N $\beta$-cells. After $4 \mathrm{~h}$ of treatment with $\mathrm{H}_{2} \mathrm{O}_{2}$, the cell viability decreased in a dose- and time-dependent manner. Compared to the controls (untreated cells), the cells treated with $0.7 \mathrm{mM} \mathrm{H}_{2} \mathrm{O}_{2}$ for $4 \mathrm{~h}$ showed a $40 \%$ decrease in viability (Fig. 3).

Effects of C3G on lipid peroxidation and ROS generation. The inhibitory effects of $\mathrm{C} 3 \mathrm{G}$ on lipid peroxidation in the $\mathrm{H}_{2} \mathrm{O}_{2}$-treated MIN6N $\beta$-cells were determined by measuring the levels of thiobarbituric acid reactive substance (TBARS), a lipid peroxidation product. Lipid peroxidation was increased in the cells exposed to $\mathrm{H}_{2} \mathrm{O}_{2}$, whereas $\mathrm{C} 3 \mathrm{G}$ inhibited lipid peroxidation. Compared to the untreated cells, the cells treated 


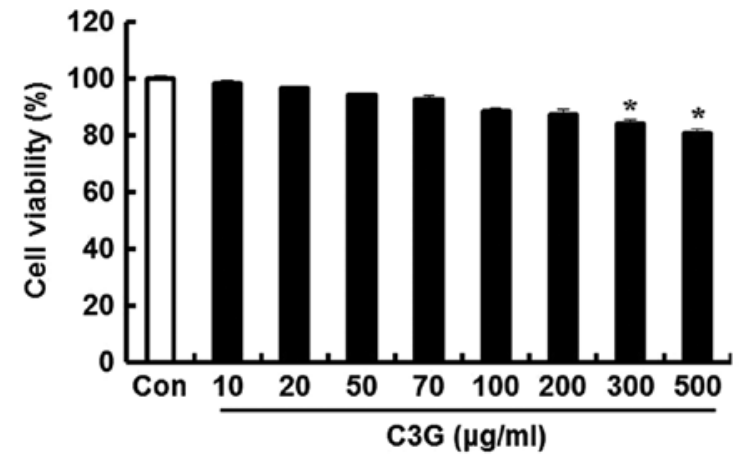

Figure 2. Viability of pancreatic MIN6N $\beta$-cells treated with various concentrations of cyanidin-3-glucoside (C3G). Dose-response experiments were performed to determine the maximum non-toxic concentration of $\mathrm{C} 3 \mathrm{G}$ Confluent cells were treated with various concentrations of $\mathrm{C} 3 \mathrm{G}(10-500 \mu \mathrm{g} / \mathrm{ml})$ for $24 \mathrm{~h}$. Data represent the means $\pm \mathrm{SE}$. ${ }^{*} \mathrm{P}<0.05$ vs. untreated control.

with 50 and $70 \mu \mathrm{g} / \mathrm{ml}$ of $\mathrm{C} 3 \mathrm{G}$ showed a 14.1 and $23.9 \%$ inhibition of lipid peroxidation, respectively (Fig. 4A). Intracellular ROS levels in the $\mathrm{H}_{2} \mathrm{O}_{2}$-treated MIN6N $\beta$-cells were determined using the ROS-sensitive fluorescent probe, $\mathrm{H}_{2}$ DCF-DA, a cell-permeable dye that is cleaved by intracellular esterases into its non-fluorescent form, 2',7'-dichlorofluorescin (DCFH). This form, which is no longer membrane permeable, can be further oxidized by $\mathrm{H}_{2} \mathrm{O}_{2}$ to form the fluorescent compound. Compared to the untreated controls, the cells treated with $\mathrm{C} 3 \mathrm{G}$ showed a significant dose-dependent increase in intracellular ROS scavenging activity $(19.4$ and $33.8 \%$ at 50 and $70 \mu \mathrm{g} / \mathrm{ml}$ C3G, respectively; Fig. 4B). The $\mathrm{H}_{2} \mathrm{O}_{2}$-dependent increase in the green fluorescence of DCF markedly decreased following treatment with $70 \mu \mathrm{g} / \mathrm{ml} \mathrm{C} 3 \mathrm{G}$ and remained similar to the levels observed in the control cells (Fig. 4C). These data suggest that $\mathrm{C} 3 \mathrm{G}$ inhibits lipid peroxidation and has ROS scavenging activity. On the basis of these results, we hypothesized that $\mathrm{C} 3 \mathrm{G}$ inhibits oxidative stress-induced apoptosis in MIN6N $\beta$-cells.

Determination of apoptotic cells. To determine whether the inhibitory effects of $\mathrm{H}_{2} \mathrm{O}_{2}$ on MIN6N $\beta$-cells are associated with apoptosis, we performed double staining using FITC-labeled Annexin V and PI. Treatment with $0.7 \mathrm{mM} \mathrm{H}_{2} \mathrm{O}_{2}$ induced apoptosis in $46.6 \%$ of the cells (Fig. 5A). However, pre-treatment with $70 \mu \mathrm{g} / \mathrm{ml} \mathrm{C} 3 \mathrm{G}$ markedly inhibited the $\mathrm{H}_{2} \mathrm{O}_{2^{-}}$ induced apoptotic cell death (32.2\%; Fig. 5B). Furthermore, DNA fragmentation upon apoptosis induced by $\mathrm{H}_{2} \mathrm{O}_{2}$ was confirmed by staining the chromatin of the MIN6N $\beta$-cells using Hoechst 33342. Only the $\mathrm{H}_{2} \mathrm{O}_{2}$-treated MIN6N $\beta$-cells underwent DNA fragmentation. The changes in chromatin condensation diminished following pre-treatment with $70 \mu \mathrm{g} /$ $\mathrm{ml}$ of $\mathrm{C} 3 \mathrm{G}$ (Fig. 5C). These results indicate that $\mathrm{C} 3 \mathrm{G}$ exerts protective effects against oxidative stress-induced apoptosis in MIN6N $\beta$-cells by inhibiting DNA fragmentation.

Effects of C3G on the phosphorylation of ERK and 38 MAPK. In order to further examine the effects of $\mathrm{C} 3 \mathrm{G}$ on $\mathrm{H}_{2} \mathrm{O}_{2}$ induced MIN6N $\beta$-cell apoptosis, we examined the effects of $\mathrm{C} 3 \mathrm{G}$ on the phosphorylation of MAPKs (ERK, JNK and p38) by western blot analysis. The levels of the phosphorylated forms of ERK, JNK and p38 significantly increased following treatment with $\mathrm{H}_{2} \mathrm{O}_{2}$ for $4 \mathrm{~h}$. By contrast, treatment with $70 \mu \mathrm{g} /$ $\mathrm{ml}$ of $\mathrm{C} 3 \mathrm{G}$ inhibited the $\mathrm{H}_{2} \mathrm{O}_{2}$-induced phosphorylation of ERK and p38, but $\mathrm{C} 3 \mathrm{G}$ did not inhibit the phosphorylation of JNK (Fig. 6A).

$C 3 G$ regulates the activation of apoptosis-related proteins. Recent studies have demonstrated that the phosphorylation of MAPKs is involved in the regulation of the mitochondrial permeability-mediated activation of apoptotic proteins, such as proteins of the Bcl-2 family and cytochrome $c$ (Cyt c) (17-19). In this study, we confirmed the release of Cyt $\mathrm{c}$ and the induction of the expression of proteins of the Bcl-2 family, including Bcl-2 and Bax, in the MIN6N $\beta$-cells. The expression of Bcl-2 decreased and that of Bax increased in the $\mathrm{H}_{2} \mathrm{O}_{2}$-treated cells (Fig. 6B). By contrast, the expression levels of proteins of the Bcl-2 family in the group pre-treated with $70 \mu \mathrm{g} / \mathrm{ml}$ of $\mathrm{C} 3 \mathrm{G}$ were similar to those of the controls. Subsequently, we investigated whether $\mathrm{H}_{2} \mathrm{O}_{2}$ induces the release of Cyt $\mathrm{c}$ from the mitochondria to the cytosol. Western blot analysis of the cytosolic fraction revealed the significant release of Cyt c from the mitochondria of the cells cultured with $\mathrm{H}_{2} \mathrm{O}_{2}$. However, treatment with C3G (50 and $70 \mu \mathrm{g} / \mathrm{ml})$ induced a dose-dependent inhibition of the release of Cyt c.

Effect of $\mathrm{C} 3 \mathrm{G}$ on $\mathrm{H}_{2} \mathrm{O}_{2}$-induced caspase-3 activity and cell death. We examined the effects of $\mathrm{C} 3 \mathrm{G}$ on the $\mathrm{H}_{2} \mathrm{O}_{2}$-induced
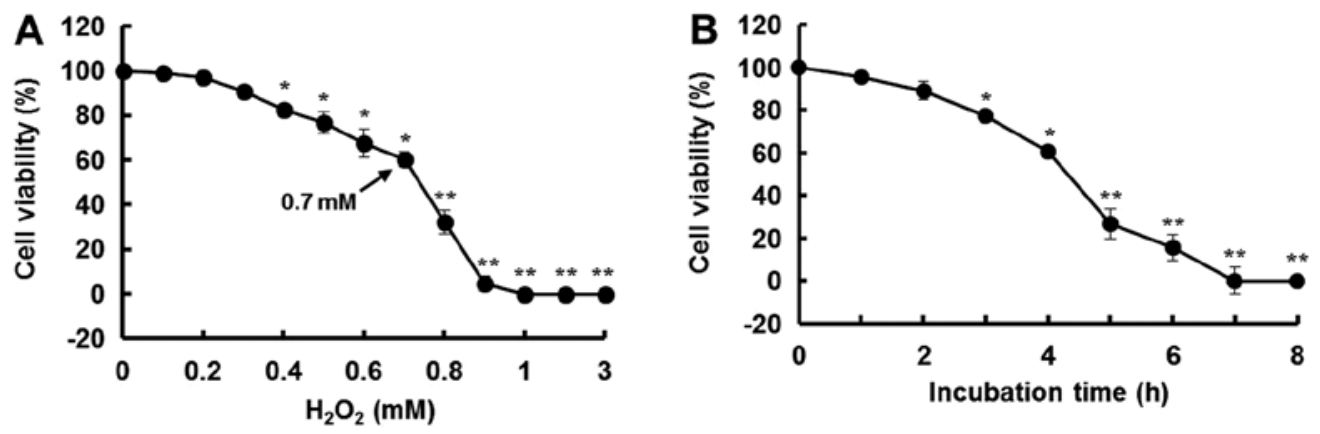

Figure 3. Viability of pancreatic MIN6N $\beta$-cells exposed to $\mathrm{H}_{2} \mathrm{O}_{2}$. (A) The cytotoxicity of $\mathrm{H}_{2} \mathrm{O}_{2}$ was examined following exposure to various concentrations of $\mathrm{H}_{2} \mathrm{O}_{2}$ for $4 \mathrm{~h}$. (B) The cytotoxicity of $\mathrm{H}_{2} \mathrm{O}_{2}$ was examined following exposure for different periods of time to $0.7 \mathrm{mM} \mathrm{H}_{2} \mathrm{O}_{2}$. Data represent the means $\pm \mathrm{SE}$. ${ }^{*} \mathrm{P}<0.05$ and ${ }^{* *} \mathrm{P}<0.01$ vs. untreated control. 

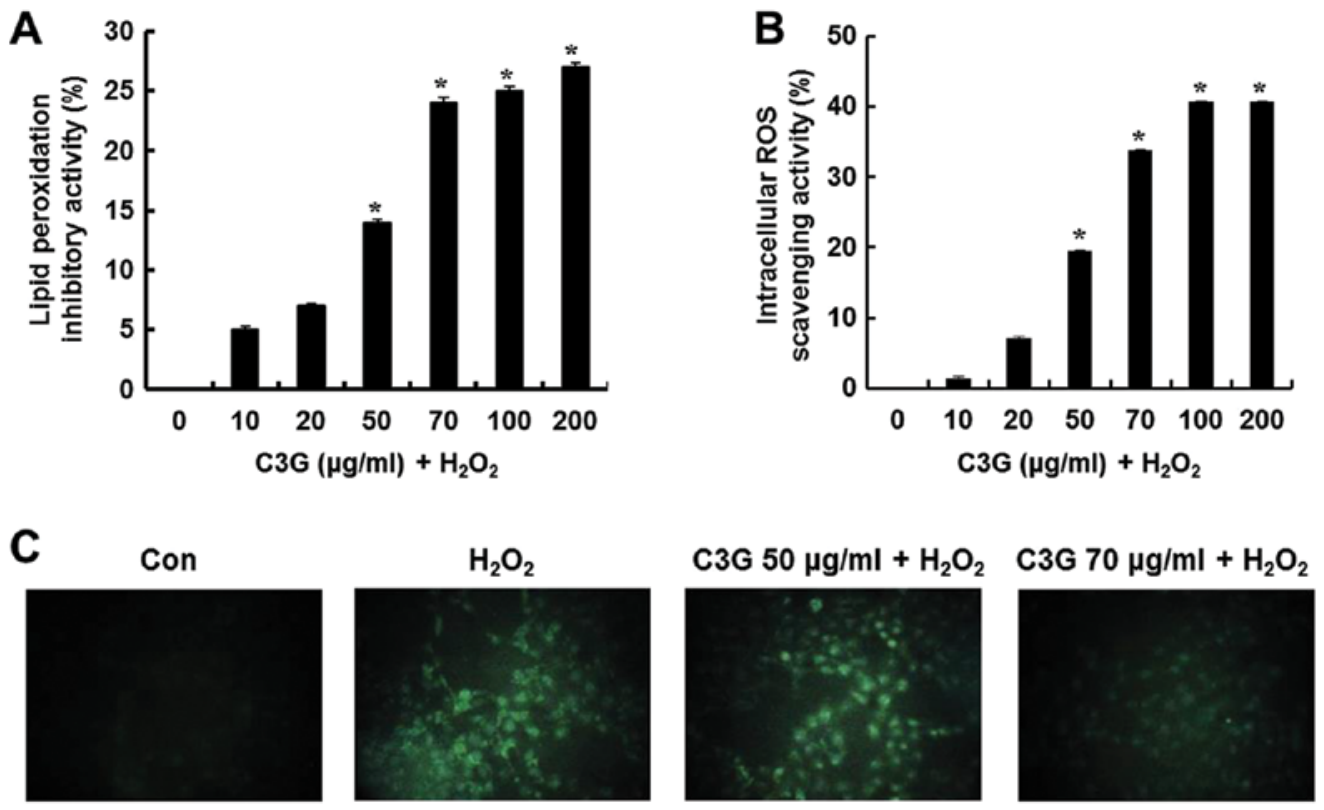

Figure 4. Inhibitory effects of cyanidin-3-glucoside (C3G) on $\mathrm{H}_{2} \mathrm{O}_{2}$-induced lipid peroxidation and reactive oxygen species (ROS) generation in MIN6N $\beta$-cells (A) Lipid peroxidation in the treated cells was assayed by measuring the amount of thiobarbituric acid reactive substance (TBARS) formation. (B) The intracellular ROS scavenging activity was measured using the DCF-DA method. Data represent the means $\pm \mathrm{SE}$. "P<0.05 vs. untreated control. (C) The ROS levels in MIN6N $\beta$-cells were determined by fluorescence microscopy.
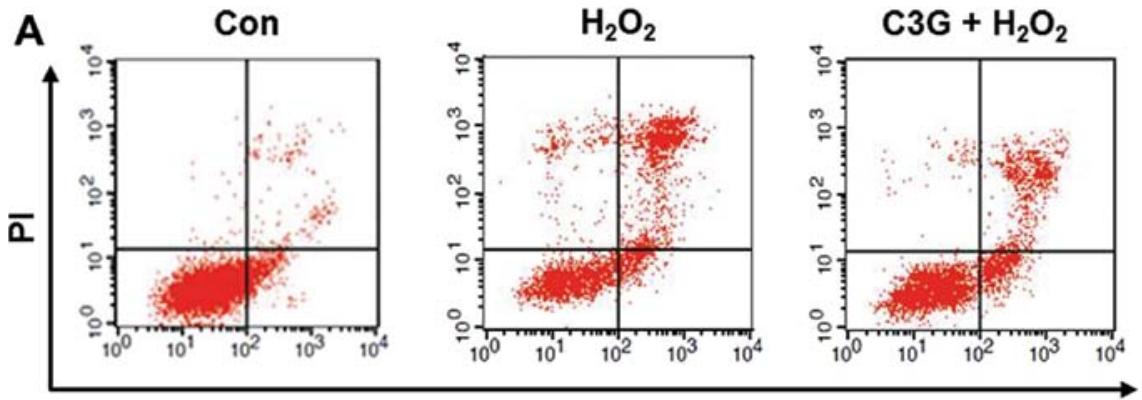

Annexin-V

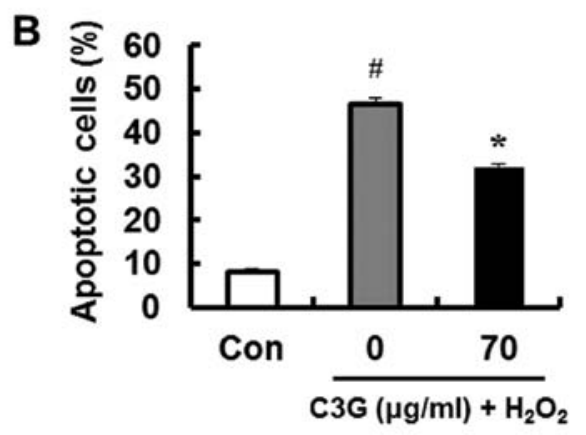

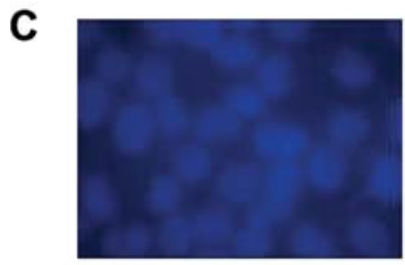

Con

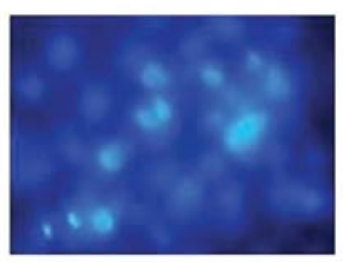

$\mathrm{H}_{2} \mathrm{O}_{2}$

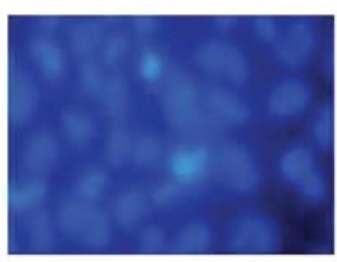

$\mathrm{C} 3 \mathrm{G}+\mathrm{H}_{2} \mathrm{O}_{2}$

Figure 5. Inhibitory effects of cyanidin-3-glucoside (C3G) on apoptotic cell death of $\mathrm{H}_{2} \mathrm{O}_{2}$-treated MIN6N $\beta$-cells. (A) Apoptotic cells were detected Annexin V and PI double staining and analyzed by flow cytometry. Cells were either untreated [controls (Con), treated with $0.7 \mathrm{mM} \mathrm{H}_{2} \mathrm{O}_{2}$, or treated with $70 \mu \mathrm{g} / \mathrm{ml}$ $\mathrm{C} 3 \mathrm{G}+0.7 \mathrm{mM} \mathrm{H}_{2} \mathrm{O}_{2}$. (B) The graph represents the percentage of apoptotic cells from the upper right plus lower right quadrants. Data represent the means \pm SE. ${ }^{\#} \mathrm{P}<0.05$ vs. control; ${ }^{*} \mathrm{P}<0.05$ vs. $\mathrm{H}_{2} \mathrm{O}_{2}$ alone. (C) The DNA fragmentation in MIN6N $\beta$-cells was determined by staining with the fluorescent dye, Hoechst 33342 . 
A

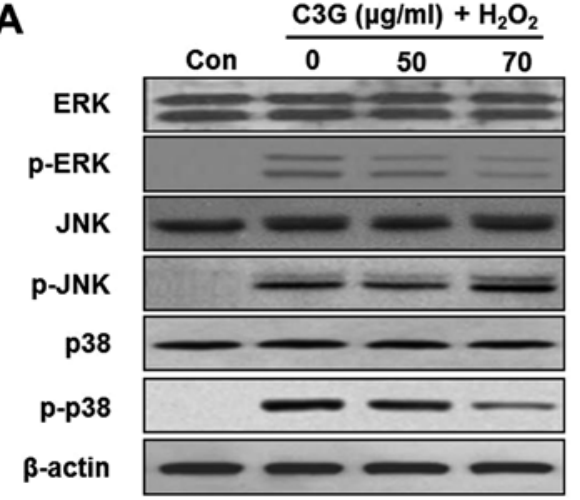

B

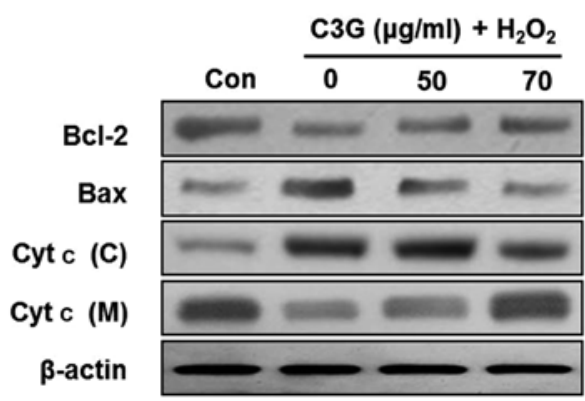

Figure 6. Effects of cyanidin-3-glucoside (C3G) on apoptosis-related proteins in $\mathrm{H}_{2} \mathrm{O}_{2}$-treated MIN6N $\beta$-cells. The treated cells were harvested and lysates were

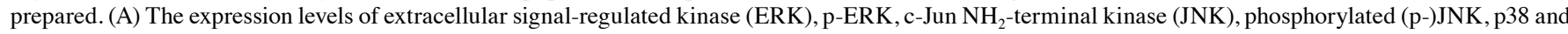
p-p38 were assessed by western blot analysis. (B) The expression levels of Bcl-2 family proteins and fractional cytochrome $c$ (Cyt c; C, cytosolic fraction; $\mathrm{M}$, mitochondrial fraction) were determined by western blot analysis. Equal loading of total proteins in each sample was verified by $\beta$-actin expression.
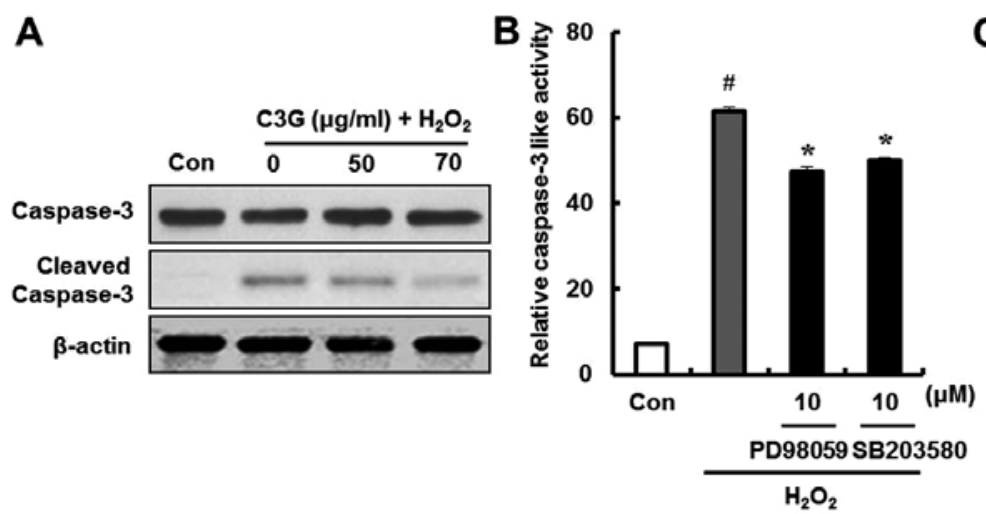
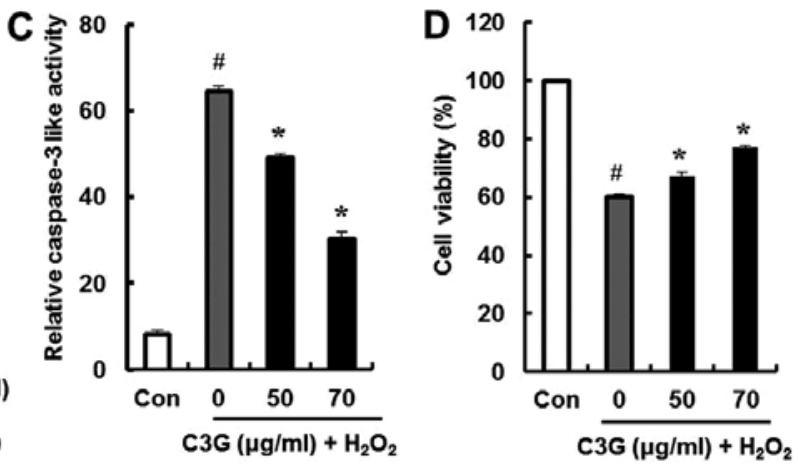

Figure 7. Effects of cyanidin-3-glucoside (C3G) on caspase-3 activation in $\mathrm{H}_{2} \mathrm{O}_{2}$-treated MIN6N $\beta$-cells. The treated cells were harvested and lysates were prepared. (A) The expression levels of caspase-3 and cleaved caspase-3 were assessed by western blot analysis. Equal loading of total proteins in each sample was verified by $\beta$-actin expression. (B and C) Effect of the MAPK inhibitors (PD98059 and SB203580) and C3G on caspase-3 activation in $\mathrm{H}_{2} \mathrm{O}_{2}$-treated MIN6N $\beta$-cells. (B) The cells were pre-treated with different types of inhibitors (10 $\mu \mathrm{M}$ PD98059 and $10 \mu \mathrm{M} \mathrm{SB} 203580)$ or (C) indicated concentrations of C3G; after the treatments, the cells were exposed to $0.7 \mathrm{mM} \mathrm{H}_{2} \mathrm{O}_{2}$ for $4 \mathrm{~h}$. Preparation of cell lysates and measurement of caspase-3 like activity was carried out using a caspase assay kit according to the manufacturer's instructions (BD Biosciences). (D) Effects of C3G on cell viability in $\mathrm{H}_{2} \mathrm{O}_{2}$-treated MIN6N $\beta$-cells. Data represent the means \pm SE. ${ }^{*} \mathrm{P}<0.05$ vs. control; ${ }^{*} \mathrm{P}<0.05$ vs. $\mathrm{H}_{2} \mathrm{O}_{2}$ alone.

expression of cleaved caspase- 3 , which is an essential trigger of apoptosis, by western blot analysis. The cleaved form of caspase-3 was detected in the $\mathrm{H}_{2} \mathrm{O}_{2}$-treated group. However, compared to the group treated with $\mathrm{H}_{2} \mathrm{O}_{2}$, the group treated with C3G $(50$ and $70 \mu \mathrm{g} / \mathrm{ml}$ ) showed a decrease in the expression of cleaved caspase-3 (Fig. 7A). In addition, the ERK and p38 inhibitors, PD98059 and SB203580, were used to confirm that C3G inhibited the $\mathrm{H}_{2} \mathrm{O}_{2}$-induced caspase- 3 activation by regulating the phosphorylation of ERK and p38. The $\mathrm{H}_{2} \mathrm{O}_{2}$-induced increase in caspase- 3 activity was significantly decreased by the ERK and p38 inhibitors, PD98059 and SB203580 (Fig. 7B); by contrast, pre-treatment with $\mathrm{C} 3 \mathrm{G}$ significantly decreased the $\mathrm{H}_{2} \mathrm{O}_{2}$-induced caspase-3 activity (Fig. 7C). Additionally, the cytoprotective effects of $\mathrm{C} 3 \mathrm{G}$ against the $\mathrm{H}_{2} \mathrm{O}_{2}$-induced death of MIN6N $\beta$-cells were examined by MTT assay. The cells were pre-treated with $\mathrm{C} 3 \mathrm{G}(50$ and $70 \mu \mathrm{g} / \mathrm{ml})$ for $20 \mathrm{~h}$ followed by treatment with $\mathrm{H}_{2} \mathrm{O}_{2}$. The cell viability decreased to $60 \%$ following treatment with $\mathrm{H}_{2} \mathrm{O}_{2}$; however, pre-treatment

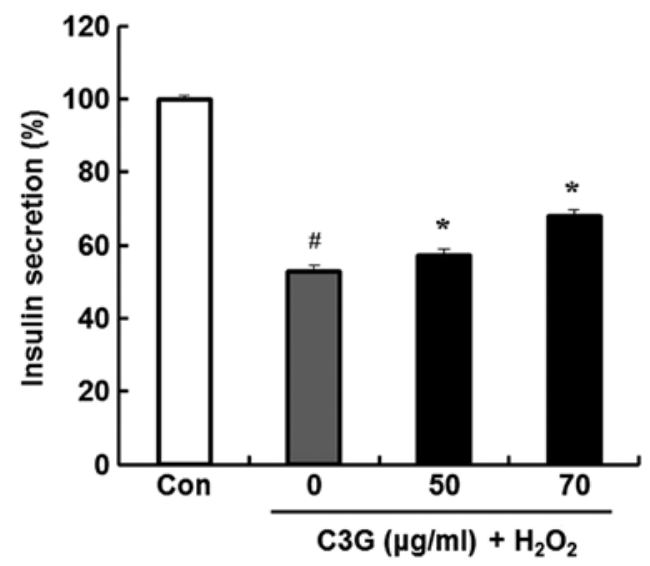

Figure 8. Effects of cyanidin-3-glucoside $(\mathrm{C} 3 \mathrm{G})$ on insulin secretion in $\mathrm{H}_{2} \mathrm{O}_{2}$-treated MIN6N $\beta$-cells. After the treatments, the supernatants were collected, and insulin release was measured using a rat/mouse insulin enzymelinked immunosorbent assay kit. Data represent the means \pm SE. ${ }^{\#} \mathrm{P}<0.05$ vs. control; ${ }^{\mathrm{P}}<0.05$ vs. $\mathrm{H}_{2} \mathrm{O}_{2}$ alone. 
with 50 and $70 \mu \mathrm{g} / \mathrm{ml}$ of $\mathrm{C} 3 \mathrm{G}$ restored the cell viability to 67.8 and $76.1 \%$ of the controls, respectively (Fig. 7D). These results suggest that $\mathrm{C} 3 \mathrm{G}$ protects pancreatic $\beta$-cells against death by inactivating caspase- 3 and regulating the phosphorylation of ERK and p38.

Effects of $\mathrm{C} 3 \mathrm{G}$ on $\mathrm{H}_{2} \mathrm{O}_{2}$-induced insulin secretion. The anti-diabetic efficacy of $\mathrm{C} 3 \mathrm{G}$ was determined by examining the effects of $\mathrm{C} 3 \mathrm{G}$ on insulin release in MIN6N $\beta$-cells; we measured insulin secretion using a rat/mouse insulin enzymelinked immunosorbent assay kit. Compared to the untreated group, the group pre-treated with $70 \mu \mathrm{g} / \mathrm{ml}$ of C3G showed an increase in insulin secretion (52.6 vs. 68\%) (Fig. 8).

\section{Discussion}

Deficiency of insulin caused by the destruction of pancreatic $\beta$-cells induces hyperglycemia, which leads to diabetes and serious pathological effects in humans $(20,21)$. ROS are heavily implicated in the process of pancreatic $\beta$-cell destruction (22). ROS are routinely generated in the human body, and their production can be exacerbated by lifestyle choices, including eating, drinking and smoking habits (23). These factors can predispose individuals to diseases associated with ROS production, including cancer, stroke, cardiac disorders and diabetes (24-26). Thus, the inhibition of ROS generation is an important therapeutic goal. In apoptosis-inducing processes, $\mathrm{H}_{2} \mathrm{O}_{2}$ generation is attributed to the uncoupling of the electron transport chain in the mitochondria and to a decrease in mitochondrial membrane potential, leading the mitochondrial translocation of Bax and the cytosolic mobilization of Cyt c. Moreover, $\mathrm{H}_{2} \mathrm{O}_{2}$ has also been shown as a strong signal for the activation of the MAPK family of signaling proteins comprising of JNK, p38 and ERK (27). In this study, we used the $\mathrm{H}_{2} \mathrm{O}_{2}$-induced toxicity of pancreatic $\beta$-cells as a model to evaluate the antidiabetic efficacy of $\mathrm{C} 3 \mathrm{G}$ isolated from mulberry fruit. Pre-treatment with $\mathrm{C} 3 \mathrm{G}$ reduced the levels of intracellular ROS and lipid peroxidation in the MIN6N cells treated with $\mathrm{H}_{2} \mathrm{O}_{2}$ (Fig. 4). In addition, the cells exposed to $\mathrm{H}_{2} \mathrm{O}_{2}$ showed distinct characteristics of apoptosis, such as DNA fragmentation and an increase in Annexin V staining. However, the cells pre-treated with $\mathrm{C} 3 \mathrm{G}$ showed a significantly decreased percentage of apoptotic cells (Fig. 5). Studies have suggested that oxidative stress causes pancreatic $\beta$-cell apoptosis through the MAPK signaling pathway $(28,29)$. MAPK proteins play a substantial role in the regulation of cell viability, proliferation and differentiation (30). The excessive accumulation of intracellular ROS activates MAPKs, which leads to apoptosis through the negative regulation of downstream proteins, such as proteins belonging to the Bcl-2 family, Cyt $\mathrm{c}$ and caspase-3 (31). Therefore, we confirmed the phosphorylation of MAPKs, the activation of $\mathrm{Bcl}-2$ family proteins and the release of Cyt $\mathrm{c}$ from the mitochondria to the cytosol in the MIN6N $\beta$-cells damaged by $\mathrm{H}_{2} \mathrm{O}_{2}$. All MAPKs were phosphorylated by treatment with $\mathrm{H}_{2} \mathrm{O}_{2}$ for $4 \mathrm{~h}$. The cells treated with $\mathrm{H}_{2} \mathrm{O}_{2}$ showed an increase in the expression of the pro-apoptotic protein, Bax, and a decrease in the anti-apoptotic protein, Bcl-2. We confirmed the release of Cyt cfrom the mitochondria to the cytosol in the cells treated with $\mathrm{H}_{2} \mathrm{O}_{2}$; subsequently, cytosolic Cyt $\mathrm{c}$ activates caspase-3, which plays an important role in the apoptotic pathway, and leads to cell apoptosis. However, we demonstrated that pre-treatment with $\mathrm{C} 3 \mathrm{G}$ exerted protective effects against $\mathrm{H}_{2} \mathrm{O}_{2}$-induced apoptosis by regulating the phosphorylation of ERK and p38. In addition, C3G regulated the proteins downstream of the MAPK signaling pathway, which resulted in the inactivation of caspase-3 (Figs. 6 and 7). Insulin secretion was significantly inhibited in the MIN6N $\beta$-cells exposed to $\mathrm{H}_{2} \mathrm{O}_{2}$. By contrast, the cells treated with $70 \mu \mathrm{g} / \mathrm{ml}$ of C3G prior to exposure to $\mathrm{H}_{2} \mathrm{O}_{2}$ showed an increase in insulin secretion (Fig. 8).

In conclusion, our results demonstrate that $\mathrm{C} 3 \mathrm{G}$ isolated from mulberry fruit not only scavenges intracellular ROS and inhibits lipid peroxidation, but also regulates the apoptotic signaling pathways in pancreatic MIN6N $\beta$-cells following exposure to $\mathrm{H}_{2} \mathrm{O}_{2}$, and thus results in a decrease in the apoptotic cell rate. Thus, our findings indicate that the anthocyanin isolated from mulberry fruit may prove to be a potential therapeutic agent for the treatment of diabetes.

\section{Acknowledgements}

This study was supported by the High Value-added Food Technology Development Program, Ministry of Agriculture, Food and Rural Affairs, Republic of Korea.

\section{References}

1. Gray H and O'Rahilly S: Beta cell dysfunction in non-insulindependent diabetes mellitus. Transplant Proc 26: 366-370, 1994.

2. Demirseren DD, Emre S, Akoglu G, Arpaci D, Arman A, Metin A and Cakir B: Relationship between skin diseases and extracutaneous complications of diabetes mellitus: clinical analysis of 750 patients. Am J Clin Dermatol 15: 65-70, 2014.

3. Lv L, Zheng L, Dong D, Xu L, Yin L, Xu Y, Qi Y, Han X and Peng J: Dioscin, a natural steroid saponin, induces apoptosis and DNA damage through reactive oxygen species: a potential new drug for treatment of glioblastoma multiforme. Food Chem Toxicol 59: 657-669, 2013.

4. Ni Q, Xu G, Gao Q, Yang D and Zhang Y: Evaluation of reactive oxygen species scavenging activities and DNA damage prevention effect of Pleioblastus kongosanensis f. aureostriatus leaf extract by chemiluminescence assay. J Photochem Photobiol B 128: 115-121, 2013.

5. Gutierrez RM: Effect of the hexane extract of Piper auritum on insulin release from beta-cell and oxidative stress in streptozotocin-induced diabetic rat. Pharmacogn Mag 8: 308-313, 2012.

6. Mane C, Loonis M, Juhel C, Dufour C and Malien-Aubert C: Food grade lingonberry extract: polyphenolic composition and in vivo protective effect against oxidative stress. J Agric Food Chem 59: 3330-3339, 2011.

7. Martin MA, Fernández-Millán E, Ramos S, Bravo L and Goya L: Cocoa flavonoid epicatechin protects pancreatic beta cell viability and function against oxidative stress. Mol Nutr Food Res 58: 447-456, 2014.

8. Aramwit P, Petcharat K and Supasyndh O: Efficacy of mulberry leaf tablets in patients with mild dyslipidemia. Phytother Res 25: 365-369, 2011.

9. Song N, Pang W, Yang H, Tan L, Fu J, Li H and Jiang Y: Primary study on protective effect of mulberry extracts on Abeta25-35induced PC12 cells injury. Wei Sheng Yan Jiu 41: 925-929, 2012 (In Chinese).

10. Stefănuţ MN, Căta A, Pop R, Tanasie C, Boc D, Ienascu I and Ordodi V: Anti-hyperglycemic effect of bilberry, blackberry and mulberry ultrasonic extracts on diabetic rats. Plant Foods Hum Nutr 68: 378-384, 2013.

11. Chang JJ, Hsu MJ, Huang HP, Chung DJ, Chang YC and Wang CJ: Mulberry anthocyanins inhibit oleic acid induced lipid accumulation by reduction of lipogenesis and promotion of hepatic lipid clearance. J Agric Food Chem 61: 6069-6076, 2013. 
12. Chen PN, Chu SC, Chiou HL, Kuo WH, Chiang CL and Hsieh YS: Mulberry anthocyanins, cyanidin 3-rutinoside and cyanidin 3-glucoside, exhibited an inhibitory effect on the migration and invasion of a human lung cancer cell line. Cancer Lett 235: 248-259, 2006.

13. Jiang Y: Effects of anthocyanins derived from Xinjiang black mulberry fruit on delaying aging. Wei Sheng Yan Jiu 39: 451-453, 2010 (In Chinese).

14. Liu LK, Lee HJ, Shih YW, Chyau CC and Wang CJ: Mulberry anthocyanin extracts inhibit LDL oxidation and macrophagederived foam cell formation induced by oxidative LDL. J Food Sci 73: H113-H121, 2008.

15. Ohkawa $\mathrm{H}$, Ohishi $\mathrm{N}$ and Yagi K: Assay for lipid peroxides in animal tissues by thiobarbituric acid reaction. Anal Biochem 95: 351-358, 1979 .

16. Lee JH, Lee JS, Kim YR, Jung WC, Lee KE, Lee SY and Hong EK: Hispidin isolated from Phellinus linteus protects against hydrogen peroxide-induced oxidative stress in pancreatic MIN6N $\beta$-cells. J Med Food 14: 1431-1438, 2011.

17. Bian J, Wang K, Kong X, Liu H, Chen F, Hu M, Zhang X, Jiao X, Ge B, Wu Y and Meng S: Caspase- and p38-MAPK-dependent induction of apoptosis in A549 lung cancer cells by Newcastle disease virus. Arch Virol 156: 1335-1344, 2011.

18. Haddad JJ: The role of Bax/Bcl-2 and pro-caspase peptides in hypoxia/reperfusion-dependent regulation of MAPK(ERK) discordant proteomic effect of MAPK(p38). Protein Pept Lett 14: 361-371, 2007.

19. Ravindran J, Gupta N, Agrawal M, Bala Bhaskar AS and Lakshmana Rao PV: Modulation of ROS/MAPK signaling pathways by okadaic acid leads to cell death via, mitochondrial mediated caspase-dependent mechanism. Apoptosis 16: 145-161, 2011.

20. Brayman KL, Nakai I, Field J, Lloveras JJ, Farney A, Najarian JS and Sutherland DE: Intrathymic islet allografts prevent hyperglycemia and autoimmune beta-cell destruction in BB rats following transplantation in the prediabetic period. Transplant Proc 25: 284-285, 1993.

21. Nakanishi K and Watanabe C: 2008. Rate of beta-cell destruction in type 1 diabetes influences the development of diabetic retinopathy: protective effect of residual beta-cell function for more than 10 years. J Clin Endocrinol Metab 93: 4759-4766, 2008.
22. Pi J, Zhang Q, Fu J, Woods CG, Hou Y, Corkey BE, Collins S and Andersen ME: ROS signaling, oxidative stress and Nrf2 in pancreatic beta-cell function. Toxicol Appl Pharmacol 244: 77-83, 2010.

23. Sasaki T, Unno K, Tahara S and Kaneko T: Age-related increase of reactive oxygen generation in the brains of mammals and birds: is reactive oxygen a signaling molecule to determine the aging process and life span? Geriatr Gerontol Int 10 (Suppl 1): S10-S24, 2010

24. Liu Z, Celotto AM, Romero G, Wipf P and Palladino MJ: Genetically encoded redox sensor identifies the role of ROS in degenerative and mitochondrial disease pathogenesis. Neurobiol Dis 45: 362-368, 2012.

25. Tsedensodnom O and Sadler KC: ROS: redux and paradox in fatty liver disease. Hepatology 58: 1210-1212, 2013.

26. Zhang C, Liu J, Pan H, Yang X and Bian K: Mitochondrial dysfunction induced by excessive ROS/RNS-metabolic cardiovascular disease and traditional Chinese medicines intervention. Zhongguo Zhong Yao Za Zhi 36: 2423-2428, 2011 (In Chinese).

27. Pervaiz S and Clément MV: Hydrogen peroxide-induced apoptosis: oxidative or reductive stress? Methods Enzymol 352: 150-159, 2002.

28. Chen CH, Chen SJ, Su CC, Yen CC, Tseng TJ, Jinn TR, Tang FC, Chen KL, Su YC, Lee KI, Hung DZ and Huang CF: Chloroacetic acid induced neuronal cells death through oxidative stress-mediated p38-MAPK activation pathway regulated mitochondria-dependent apoptotic signals. Toxicology 303: 72-82, 2013.

29. Supanji, Shimomachi M, Hasan MZ, Kawaichi M and Oka C: HtrA1 is induced by oxidative stress and enhances cell senescence through p38 MAPK pathway. Exp Eye Res 112: 79-92, 2013.

30. Cargnello M and Roux PP: Activation and function of the MAPKs and their substrates, the MAPK-activated protein kinases. Microbiol Mol Biol Rev 75: 50-83, 2011.

31. Fu YC, Yin SC, Chi CS, Hwang B and Hsu SL: Norepinephrine induces apoptosis in neonatal rat endothelial cells via a ROS-dependent JNK activation pathway. Apoptosis 11: 2053-2063, 2006. 